\title{
Guided Inquiry Based Biological Teaching Materials to Improve Science Process Skills of Junior High School Students
}

\author{
I Putu Artayasa* \\ Biology Education \\ University of Mataram \\ Mataram, Indonesia \\ artayasa75@unram.ac.id \\ Gito Hadiprayitno \\ Biology Education \\ University of Mataram \\ Mataram, Indonesia \\ gitohadiprayitno@unram.ac.id
}

\author{
M Muhlis \\ Biology Education \\ University of Mataram \\ Mataram, Indonesia \\ muhlis.ocean@Yahoo.co.id \\ I Wayan Merta \\ Biology Education \\ University of Mataram \\ Mataram, Indonesia \\ wayanmerta.fkip@unram.ac.id
}

\begin{abstract}
Science process skills are an indispensable ability in studying science because they are positively correlated with student science learning outcomes. The development of science process skills in junior high school students can be facilitated through the application of teaching materials based on guided inquiry learning. The purpose of this study was to develop science teaching materials on appropriate biology materials using a guided inquiry model to improve the science process skills of junior high school students. The development of teaching materials is carried out through the application of the $4 \mathrm{D}$ development model which is focused on the Define, Design and Develop stages. The teaching materials developed are in the form of teaching materials and students' worksheet which emphasize the application of science process skills and concept map preparation. The feasibility test of teaching materials was carried out by three experts consisting of material experts and junior high school science teachers. The feasibility test is also equipped with student assessment of the teaching materials being developed. The instrument for the feasibility test is in the form of a questionnaire with a score based on a Likert scale of 1-4. There are three indicators for the assessment of teaching materials including presentation, content, and language. The results showed the average score for the assessment of teaching materials from experts on indicators of content, presentation, and language, respectively $87 \%, 84 \%$, and $85.5 \%$ with an average of $85 \%$, while students gave an average feasibility score. by $80 \%$. The conclusion of the study is that the teaching materials developed are very suitable to be used to support the improvement of science process skills of junior high school students.
\end{abstract}

Keywords - concept maps, guided inquiry learning, science process skills

\section{I.INTRODUCTION}

Science process skills are very important abilities that students have in supporting the implementation of science learning, because these skills not only provide provisions for students to handle problems of daily life, but also help improve student learning outcomes. Science process skills are mental and physical abilities needed to make it easier to learn science and technology and solve individual and social problems [1], [2]. The relationship between science process skills and students' science abilities was stated by Feyzioglu [3] that science process skills correlated significantly positively to students' science abilities. Similar opinion was presented by Feyzioglu et al.[4] that science process skills are the main abilities needed to develop students' scientific literacy. A more detailed opinion was expressed by Irwanto et al.[5] that the increase of students' science process skills has an effect on improving their thinking skills, inquiry activities, problem solving, and creativity.

The important role of science process skills in science learning makes it the main activity in the implementation of junior high school science learning. This is evidenced by the establishment of a scientific approach which includes activities to observe, ask questions, collect information or conduct experiments, process information and communicate information, which are part of science process skills, as the main motor of the 2013 curriculum implementation. student science process in Indonesia still needs to be improved. The results of research by Irwanto et al. [5] shows that the achievement of basic science process skills of Indonesian students in science lessons is still in the medium category, while integrated process skills, such as making experimental designs and processing experimental results, are in the low category. The same thing was said by Artayasa et al. [6] and Subali [7] that students have difficulty applying integrated skills, such as making experimental steps and presenting observational data into tables and graphs.

Indications of the low science process skills of junior high school students in Indonesia can also be seen from the evaluation results of the Program for International Student Assessment (PISA) towards students' scientific literacy. The results showed that Indonesian students are always in the bottom 10 of the $60-70$ countries that follow the PISA evaluation[8], [9]. The results of Lestari's research [10] on 248 students spread across five junior high schools in Mataram City showed that almost $50 \%$ of students had low and very low categories of scientific literacy scores, and only $5 \%$ had high scores of scientific literacy. The average science literacy score of the junior high school students was 53 which 
was in the low category. Research on science teachers at SMP Kota Mataram also showed that $50 \%$ of the teachers studied had low category science literacy scores [11]. Based on the results of this study, serious efforts need to be made as soon as possible to improve the scientific literacy of Indonesian students.

Increasing students' scientific literacy requires mastery of good science process skills, because scientific literacy is positively correlated with science process skills [4]. According to Anggraini [12], conventional learning that has been applied so far is not optimal in facilitating the development of students' science process skills. Nworgu and Otum [13] recommend that it is better to apply inquiry learning to improve students' process skills. The same opinion is stated that students who implement inquiry learning have better scientific abilities than those who implement conventional learning [14]. The increase in science process skills is higher in guided inquiry classes compared to conventional classes because of the contribution of students' inquiry activities which include designing experiments, processing data and concluding experimental results [15].

The low science ability of students in Indonesia is also influenced by the selection of teaching materials used in schools [16]. According to Deswita and Hufri [17], teaching materials used in schools usually only contain subject matter that does not require students to find learning concepts and solving problems they face. The analysis of students' worksheets employed in teaching and learning process by the Junior High School's science teachers at Mataram City showed that the students were trained a lot to explain phenomena scientifically and has less effort to train science process skills, such as designing scientific investigations, interpreting data and proving scientific investigations. Thus, it is necessary to study teaching materials and science learning models that are effective in improving the science process skills of junior high school students.

Based on the results of observations and analysis of teaching materials for class VIII Junior High School (revised 2017), lesson plan, syllabus and questions conducted by Hijrati at MTs Negeri 2 Mataram, the science teaching materials used have not actually included inquiry activities that can be easily carried out by students and teachers every time. face to face [18]. According to Permana et al. [19] teaching material will be better if it encourages students to have inquiry abilities. Hijrati [18] added that science learning activities carried out through inquiry activities can train students' science process skills. Thus, in this study, appropriate guided inquiry-based teaching materials were developed as an effort to improve the science process skills of junior high school students.

\section{II.METHODS}

The teaching materials developed consist of teaching materials and Student Worksheets (LKPD). The topics taken in the teaching material are based on Basic Competency (KD) in science subjects for Junior High School class VIII in the first semester of the 2013 curriculum. There are four basic competencies that are used as references in developing this science teaching material, namely KD 3.1 and KD 4.1 regarding the movement system of living things, and KD 3.4 and 4.4 regarding the structure and function of plants.

The stages of developing this teaching material are based on the $4 \mathrm{D}$ model from Thiagarajan (1974), which consists of four stages, but in this study it is adapted into three stages, namely from the Define, Design stage, to the Develop stage, which is carried out through due diligence by material experts and curriculum and students. The first stage of developing teaching materials is called by Define. This stage is carried out to determine the requirements and competencies that students must achieve after carrying out the learning. The definition of the requirements and the potential that must be achieved will determine the objectives of the limits of the teaching materials being developed. In this study, the objectives and teaching materials developed were based on the basic competencies that students had to achieve according to the standard content of science subjects for class VIII in the first semester of the 2013 curriculum. Thus, the results of the first stage of this development were teaching materials developed based on KD 3.1, 4.1, 3.4. and KD 4.4 from the junior high school science subject.

The second stage of the development of teaching materials is called by Design. The design stage is the stage of designing a product in the form of science teaching materials on the motion system material and the structure and function of plants. The teaching materials designed contain activities to apply scientific process skills in the guided inquiry learning model, which begins with the activity of compiling hypotheses based on the questions presented on the first page of the teaching materials, making steps for retrieval of investigative data, presenting investigation data and concluding. In this teaching material, an incomplete concept map is also presented so that students are asked to complete the concept map. The purpose of drafting the concept map is to focus the mind and direct students to develop investigative activities. The concept map is presented before and after the student completes the investigation. The result of this second stage is the initial product in the form of a draft of teaching materials about the motion system in living things and the structure and function of plants.

The third stage is called by Develop. At this stage, revised teaching materials are produced based on input from experts. This stage includes activities (a) validation of teaching materials by experts, namely lecturers and teachers of junior high school science subjects. The results of expert validation will be the basis for revision of teaching materials, and (b) limited trials for students. The limited trial was conducted on ten respondents consisting of five students of SMPN 3 Mataram and five students of SMPN 7 Mataram, both are junior high schools located in Mataram. Validators and students give scores on a Likert scale, from 1 to 4 and the average score of the validators and students is then concluded according to the criteria proposed by Akbar [20], as in Table I. 
TABLE I. TEACHING MATERIAL ELIGIBILITY CRITERIA

\begin{tabular}{|l|l|}
\hline \multicolumn{1}{|c|}{ Average Value (RN) (\%) } & \multicolumn{1}{c|}{ Criteria } \\
\hline $81 \leq \mathrm{RN}<100$ & Very Eligible \\
\hline $62 \leq \mathrm{RN}<81$ & Eligible \\
\hline $43 \leq \mathrm{RN}<62$ & Eligible enough \\
\hline $33 \leq \mathrm{RN}<43$ & Less Eligible \\
\hline $\mathrm{RN}<33$ & Not Eligible \\
\hline
\end{tabular}

\section{III.RESULTS AND DISCUSSION}

The teaching materials developed have gone through expert testing and junior high school students. The teaching materials developed were tested by three validators, namely one lecturer in the Biology Education Study Program, two teachers, and a limited trial was conducted on ten students from SMPN 3 Mataram and SMPN 7 Mataram. The three validators assessed the feasibility of teaching materials, while the student respondents gave an assessment of the feasibility in terms of the attractiveness of the teaching materials. The feasibility of teaching materials is viewed from three main aspects, namely aspects of content feasibility, presentation feasibility, and language feasibility. The assessment of the content aspects of teaching materials is focused on the assessment of teaching materials, while the assessment of the aspects of presentation is carried out on the evaluation of the layout and graphics of teaching materials. Meanwhile, language musty assessment is carried out by assessing the arrangement of words and terms in the teaching material.

The first teaching material is about the movement system of living things. The content of this teaching material is the motion system in plants, animals and humans. The presentation of this teaching material starts from the cover of the teaching material, a description of the competence that must be achieved by students, a description of the material for the motion system, and students' worksheet in the form of a student inquiry activity guide. In the student activity guide, there are several activities that ask students to investigate plants and animals around their school or house and apply science process skills. The application of these process skills is carried out through the preparation of hypotheses based on the questions presented on the first page of the inquiry activity guide. Then students are asked to complete a concept map that serves to guide them in making their own investigation designs and collecting investigation data. Learning that gives students the opportunity to make their own investigation designs based on the problems given by the teacher is a feature of the application of guided inquiry learning [22]. Then, the student inquiry activity guide ends by asking students to make conclusions from their investigations. Based on the inquiry activity guide, it appears that students are given the opportunity to carry out investigations while practicing their science process skills. According to Nworgu and Otum [14], various investigative activities carried out by students can lead to a maximum increase in science process skills.

Based on validator testing, the feasibility of teaching materials on the motion system material is presented in Table II.

TABLE II. RESUlts OF THE FEASIBILITY OF TEACHING MATERIALS FOR THE MOTION SYSTEM OF LIVING THINGS ACCORDING TO THE VALIDATOR

\begin{tabular}{|l|c|c|c|c|c|}
\hline \multirow{2}{*}{ Aspect } & \multicolumn{3}{|c|}{ Validator } & \multirow{2}{*}{ Average } & $\begin{array}{c}\text { Score } \\
(\%)\end{array}$ \\
\cline { 2 - 4 } & $\mathbf{1}$ & $\mathbf{2}$ & $\mathbf{3}$ & & \\
\hline Contents & 0.90 & 0.87 & 1.00 & 0.92 & 92 \\
\hline Presentation & 0.87 & 0.83 & 0.87 & 0.86 & 86 \\
\hline Language & 0.86 & 0.79 & 0.96 & 0.87 & 87 \\
\hline Average
\end{tabular}

The data in Table II shows that the three validators gave an average score between $86 \%$ and $92 \%$ or an average score of $88 \%$. So, when consulted with the criteria proposed by Akbar [20], the score indicates that the teaching materials developed are in the very feasible category. The results of the student's assessment of the motion system teaching materials in living things showed an average of $82 \%$ (Table III), so that according to the students the teaching material was also very feasible. Some of the suggestions given by the validator and students were to present clearer and observable images in everyday life, and shorten long sentences to make them easier for students to understand.

TABLE III. THE APPROPRIATENESS OF THE TEACHING MATERIALS FOR THE MOVEMENT OF LiVING THINGS ACCORDING TO THE STUDENTS

\begin{tabular}{|c|c|c|c|c|c|c|c|c|c|c|c|c|}
\hline & \multicolumn{9}{|c|}{ Students } & \multirow{2}{*}{$\begin{array}{c}\text { Average } \\
\text { Score }\end{array}$} & \multirow{2}{*}{ Percentage (\%) } \\
\cline { 2 - 13 } & $\mathbf{1}$ & $\mathbf{2}$ & $\mathbf{3}$ & $\mathbf{4}$ & $\mathbf{5}$ & $\mathbf{6}$ & $\mathbf{7}$ & $\mathbf{8}$ & $\mathbf{9}$ & $\mathbf{1 0}$ & 3.27 & 82 \\
\hline Score & 3.87 & 3.53 & 3.87 & 3.73 & 3.00 & 3.00 & 3.00 & 2.93 & 3.13 & 2.67 & 82 \\
\hline
\end{tabular}

The second teaching material is the structure and function of plants. The presentation of teaching materials for plant material is the same as for the material for the movement of living things, starting from the cover, the competencies that are expected to be achieved by students, teaching materials, and guides for student inquiry activities. The validator's assessment of the teaching material was $82 \%$ both in the aspects of content, presentation and language, so that the teaching materials developed were also declared very feasible to be applied to junior high school students. The results of the validator's research on the feasibility of this second teaching material are summarized in Table IV.

The average score of teaching materials for motion systems and plant structures and functions according to experts and students was $85 \%$ and $80 \%$, respectively, so that the teaching materials developed were very feasible to be applied in guided inquiry-based learning. In other words, the teaching materials developed have attempted to facilitate students to carry out investigative activities or inquiry activities. Meanwhile, in these inquiry activities, there are activities that facilitate students to apply various science process skills, such as observing, formulating hypotheses, designing investigations, and making conclusions. Sahyar and Hastini [14] stated that the implementation of inquiry learning causes students to obtain good scientific process descriptions.

The average score of the students' assessment of the teaching materials for the structure and function of plants was $77.35 \%$ (Table V), so that according to the students, 
the teaching materials were considered appropriate to be applied to junior high school students. Some suggestions for improving teaching materials from the validator and students are correcting typing that is still a lot of mistakes, presenting pictures with clearer explanations, and improving the indicators of inquiry activities to make it easier for students to understand.
TABLE IV. RESUlTS OF FEASIBILITY OF Plant STRUCTURE AND FUNCTION MATERIALS ACCORDING TO THE VALIDATOR

\begin{tabular}{|c|c|c|c|c|c|}
\hline \multirow{2}{*}{ Aspect } & \multicolumn{3}{|c|}{ Validator } & Average & $\begin{array}{c}\text { Score } \\
(\boldsymbol{\%})\end{array}$ \\
\cline { 2 - 4 } & $\mathbf{1}$ & $\mathbf{2}$ & $\mathbf{3}$ & & 82 \\
\hline Content & 0.80 & 0.93 & 0,73 & 0.82 & 82 \\
\hline Presentation & 0,80 & 0,80 & 0,87 & 0.82 & 82 \\
\hline Language & 0,80 & 0,87 & 0,80 & 0.82 & 82 \\
\hline \multicolumn{7}{|c|}{ Average }
\end{tabular}

TABle V. Feasibility of Plant Structure And Function Teaching Materials AcCording to Students

\begin{tabular}{|c|c|c|c|c|c|c|c|c|c|c|c|}
\hline & \multicolumn{9}{|c|}{ Students } & \multicolumn{1}{c|}{$\begin{array}{c}\text { Average } \\
\text { Score (\%) }\end{array}$} \\
\cline { 2 - 13 } & $\mathbf{1}$ & $\mathbf{2}$ & $\mathbf{3}$ & $\mathbf{4}$ & $\mathbf{5}$ & $\mathbf{6}$ & $\mathbf{7}$ & $\mathbf{8}$ & $\mathbf{9}$ & $\mathbf{1 0}$ & 77.35 \\
\hline Score & 81.25 & 80.00 & 70.00 & 76.25 & 77.50 & 78.75 & 73.75 & 77.50 & 76.25 & 82.25 & 75.35 \\
\hline
\end{tabular}

In the developed teaching materials there is a guided inquiry activity guide. The guide aims to include inquiry activity in teaching materials without having to interfere with the achievement of the target subject matter that students must complete in the semester. In other words, the inquiry activities carried out by students refer to basic competencies and material facts, concepts and science procedures from the applicable curriculum. The existence of an inquiry activity guide in teaching materials is in accordance with the characteristics of inquiry teaching materials according to Joyce and Weil (2000) which consists of a) introducing the investigation area to students; b) find and look for problems, c) identify the problems under study; and d) determine strategies to solve problems based on the facts that found [21].

The teaching materials developed are also equipped with pictures and challenging questions related to the topics discussed. The pictures and questions are placed at the beginning of the student worksheet. The question is, for example, do fish with different body sizes have different amounts of tail fin movement? Do the tips of the stems and roots of the plant move in different directions? Are roots, stems, and leaves made up of the same network? The pictures and questions provoke students' activity who are not only looking for answers from one source but from many sources, especially by downloading various relevant reading sources on internet sites. Thus, the developed teaching materials motivate students to use a variety of learning sources both from books and from internet sources and other printed media.

The existence of inquiry activity guides, pictures and challenging questions in the teaching materials also encourage students to be more active in planning investigations and make them more independent in learning. According to Ikhsan et al. [23] Inquiry-based teaching materials can condition science learning activities that are more well-planned, independent, thorough and with clear results. Providing more opportunities for students to be responsible for research activities can increase motivation and scientific attitudes in learning [22]-[25] as well as improve students' science process skills [26].

Guidelines for inquiry activities in teaching materials are outlined in the form of students' worksheet. It contains experimental activities that students must do independently or in groups. The students' worksheet was accompanied by activities to make a concept map, as shown in Fig. 1 where students are asked to complete a concept map regarding the observation steps of earthworm motion.


Fig. 1. Concept Map on Students' Worksheets (left) and the Example of Student's Work (right)

The task of compiling a concept map in the worksheet encourages students to analyze the relationship between concepts with one another. In this teaching material, there are two kinds of concept maps that students must compile, namely the first concept map asks students to make or complete a concept map before students conduct an experiment, while the second concept map is prepared after students complete the experiment. The first concept map aims to direct students to carry out the investigative steps appropriately, while the second concept map aims to reinforce the learning that has been done. This is in accordance with the opinion of Widyastuti [27] that making concept maps makes it easier for students to develop ideas starting from a main idea and then use the connections in the brain to break down into more detailed ideas. Likewise, according to Tapantoko[28], the application of concept maps can improve students' memorization and motivation to learn and cause students to be more creative.

\section{IV.CONCLUSION}

The conclusion of the study is that the teaching materials developed are very suitable for use in guided inquiry-based learning to support the improvement of the science process skills of junior high school students.

\section{ACKNOWLEDGMENT}

Thanks are conveyed to the University of Mataram for funding this research activity through the DIPA BLU University of Mataram funding source for the 2020 fiscal year with an agreement letter number 2628 / UN18.1 / PP / 2020. Thanks are also conveyed to the teachers and 
students of SMPN 3 and 7 Mataram for the facilitation of research activities and the willingness to apply teaching materials in their student learning activities..

\section{REFERENCES}

[1] R. O. Ongowo and F. C. Indoshi, "Science process skills in the Kenya certificate of secondary education biology practical examinations," 2013.

[2] A. and F. A. A. O., "Analysis of Science Process Skills in West African Senior Secondary School Certificate Physics Practical Examinations in Nigeria," Am. J. Sci. Res., vol. 5, no. 4, pp. 234240, 2020.

[3] B. Feyzioglu, "An Investigation of The Relationship Between Science Process Skills with Efficient Laboratory Use and Science Achievement In Chemistry Education," J. Turkish Sci. Educ., vol. 6, no. 3, pp. 114-132, 2009 .

[4] B. Feyzioglu, et al., "Developing A Science Process Skills Test for Secondary Student: Validity and Reliability Study," Educ. Sci. Theory Pract., vol. 12, no. 3, pp. 1899-1906, 2012.

[5] E. R. and A. K. P. Irwanto, "Undergraduate Students' Science Process Skills in Terms of Some Variables: A Perspective from Indonesia,” J. Balt. Sci. Educ., vol. 17, no. 5, pp. 751-764, 2018.

[6] U. L. and S. E. I. I P. Artayasa, H. Susilo, "The Effectiveness of The Three Levels of Inquiry in Improving Teacher Training Students' Science Process Skills," J. Balt. Sci. Educ., vol. 16, no. 6, pp. 908-918, 2017.

[7] B. Subali, Pengembangan tes pengukuran keterampilan proses sains pola divergen mata pelajaran biologi SMA, UNY. Yogyakarta, 2009.

[8] M. Nofiana and T. Julianto, "Profil Kemampuan Literasi Sains Siswa SMP Di Kota Purwokerto Ditinjau dari Aspek Konten, Proses, dan Konteks Sains,” J. Sains Sos. dan Hum., vol. 1, no. 2, pp. 77-84, 2017.

[9] OECD, PISA 2018 Insights and Interpretations, Paris: OECD Publishing, 2019.

[10] A. Lestari, "Analisis Lembar Kerja Peserta Didik (LKPD) dan kemampuan literasi sains pada mata pelajaran Ilmu Pengetahuan Alam (IPA) Biologi Kelas VIII SMPN Di Kecamatan Mataram," Universitas Mataram, 2019.

[11] A. Ramdani and A. A. Jamaluddin, A. W. Jufri, "Profil Literasi Sains dan Keterampilan Berpikir Kritis Pendidik IPA SMP," J. Penelit. Pendidik. IPA, vol. 5, no. 1, pp. 120-130, 2019.

[12] S. Anggraini, "Profil kemampuan melakukan inkuiri melalui kegiatan miniriset calon guru biologi dalam perkuliahan fisiologi tumbuhan. Jakarta, 2012.

[13] Nworgu, L. Ngozi, and V. V. Otum, "Effect of Guided Inquiry with Analogy Instructional Strategy on Students Acquisition of Science Process Skills,” J. Educ. Pract., vol. 4, no. 27, pp. 35-41, 2013.

[14] Sahyar and F. Hastini, "The Effect of Scientific Inquiry Learning Model Based on Conceptual Change on Physics Cognitive Competence and Science Process Skill (SPS) of Students at Senior High School," J. Educ. Pract., vol. 8, no. 5, pp. 120-126, 2017.

[15] I. P. Artayasa, "Implementasi Tiga Level Inkuiri dan Pengaruhnya terhadap Kreativitas, Keterampilan Proses, dan Pemahaman Konsep IPA Mahasiswa Pendidikan Guru Sekolah Dasar," Universitas Negeri Malang, 2018.

[16] A. R. and S. A. D. Paramita, "Pengembangan Bahan Ajar Berbasis Literasi Sains Materi Suhu dan Kalor," J. Pendidik. MIPA, vol. 7, no. 1, pp. 58-67, 2017.

[17] D. Deswita and H. Hufri, "Validasi Bahan Ajar Fisika Berbasis Inkuiri pada Materi Hukum Newton Tentang Gerak dan Gravitasi untuk Meningkatkan Literasi Sains," Pillar Phys. Educ., vol. 11, no. 3, pp. 153-160, 2018.

[18] I. Hijrati, "Pengembangan Bahan Ajar Berbasis Inkuiri Dalam Meningkatkan Literasi Sains Siswa Kelas VIII pada Materi Gerak Makhluk Hidup Di MTsN 2 Mataram," Universitas Mataram, 2018.

[19] A. T. A. Permana, I. N. S. Degeng, and S. Sihkabuden, "Pengembangan Bahan Ajar Berbasis Inkuiri pada Mata Pelajaran Biologi Di SMK-PP Negeri Banjarbaru Kalimantan Selatan,"
Teknol. Pembelajaran dan Pendidik. Dasar, vol. 5, no. 3, pp. 189195, 2017.

[20] S. Akbar, Instrumen perangkat pembelajaran. Bandung: Remaja Rosdakarya, 2013.

[21] B. A. P. M. Ikhsan and, Sutamo, "Pengembangan Modul Berbasis Inkuiri Terbimbing pada Sistem Gerak Manusia Untuk Meningkatkan Hasil Belajar Siswa Kelas XI MIA SMA Negeri 1 Wera Kabupaten Bima Nusa Tenggara Barat," J. Inkuiri, vol. 5, no. 1, pp. 133-142, 2016.

[22] O. Akinoglu, "Assessment of the Inquiry-Based Project Implementation Process in Science Education Upon Students' Points of Views,” Int. J. Instr., vol. 1, no. 1, pp. 1-12, 2008.

[23] Z. Bayram et al, "Effect of Inquiry Based Learning Method on Students'Motivation," Procedia-Social Behav. Sci., vol. 106, pp. 988-996, 2013.

[24] J. L., Lin et al, "The Effects of Combining Inquiry-Based Teaching with Science Magic on The Learning Outcomes of A Friction Unit,” J. Balt. Sci. Educ., vol. 16, no. 2, pp. 218-227, 2017.

[25] H. Lintuan et al, "Investigating the Effectiveness of Inquiry Instruction on The Motivation of Different Learning Styles Students," Int. J. Math. Educ., vol. 3, pp. 541-566, 2005.

[26] T. Hardianti and H. Kuswanto, "Difference Among Levels of Inquiry: Process Skills Improvement at Senior High School in Indonesia,” Int. J. Instr., vol. 10, no. 2, pp. 119-130, 2017.

[27] S. Widyastuti, Menggunakan metode peta pikiran (maind mapping) dalam menulis," presented at the Seminar Metode Belajar yang Efektif. 2010

[28] A. A. Tapantoko, Penggunaan Metode Mind Map (Peta Pikiran) untuk Meningkatkan Motivasi Belajar Siswa dalam Pembelajaran Matematika Siswa Kelas VIII SMP Negeri 4 Depok. Universitas Negeri Yogyakarta, 2011 